\title{
Selection for Early Heading and Correlated Response in Grain Yield
} and its Components in Durum Wheat

Khalifa, E.M.A. ${ }^{1}$; K.A. Kheiralla ${ }^{2}$; M.Z. El-Hefny ${ }^{2}$ and E. Abdelrhman ${ }^{1}$

${ }^{1}$ Wheat Res. Section, Field Crops, Res. Inst. ARC, Giza, Egypt.

${ }^{2}$ Agron. Dept., Fac. Agric., Assiut University

Received on: / /2016

Accepted for publication on: / /2016

\section{Abstract}

Two cycles of selection were applied to the $\mathrm{F}_{3}$ generation of a cross between Bani Sweif 1/3/STJ3 and Bani Sweif 1/3/LKS4 lines to evaluate the effect of direct selection for heading date and correlated response in grain yield and its components. Significant differences among $\mathrm{F}_{3}$ families were found for heading date, plant height, no. of kernels/spike, spikes/plant, 100-kernel weight and grain yield/plant. Estimates of the phenotypic and genotypic coefficients of variation indicated the presence of sufficient variability for heading date and other studied traits. Phenotypic and genotypic variances expressed as PCV\% and GCV\% decreased rapidly after two cycles of selection for early heading. The results indicate that the two cycles of selection were enough to identify the early genotypes. Flowering time was reduced by 3.53 and 7.45 days after two cycles of selection compared to the earliest parent and the bulk of the $\mathrm{F}_{3}$-families, respectively. The results indicated that five out of the ten early selected families were significantly or highly significantly earlier than the earlier parent. Direct selection for early heading was accompanied by average decrease of $3.17,3.76,0.26$ and $1.95 \%$ for plant height, no. of kernels/spike, 100 kernels weight and grain yield/plant, respectively, after two cycles of selection compared to the best parent. Direct selection for early heading significantly reduced grain yield/plant by $2.31,2.45,3.20$, 5.72 and $6.98 \%$ for family no. 54, 76, 77, 68 and 50, respectively, compared with the best parent. The results should be indicated to the promising family no. 29 which was earlier and significantly increased in no. of kernels/spike, 100 grain weight and grain yield/plant.

Keywords: durum wheat, Triticum turgidum, correlated response

\section{Introduction}

Wheat is the most important grain crop in the world. It provides food to $36 \%$ of the global population, and contributes $20 \%$ of food calories, (Singh and Chaudhary, 2006). Durum wheat (Triticum turgidum var. $d u$ rum), sometimes called macaroni wheat, covers about $9 \%$ of the wheat area. Modern durum wheat cultivars are higher in grain yield than bread wheat cultivars, and the kernels of durum wheat are typically larger, heavier, and harder than those of bread wheat. In Egypt, wheat crop is considered as the essential strategic cereal crop for thousands of years. Egypt wheat yield annual consumption is about 13 million tons, while the annual local production is about 8.5 million tons in 2011 (Wheat Research, Department, Field Crops Research Institute, Agricultural Research Center, Egypt). Breeding for drought tolerance through to develop short season cultivars is nowadays widely adopted in different regions of the world where water supply is limited. A crop plant may overcome drought effects through drought 
avoidance which involves mechanisms of reducing water loss from the plant and maintaining the water uptake. Another way is drought tolerance using a mechanism which enables the plant to withstand low tissue water potential. A third way is to escape drought through earliness of maturity (Clark and Townley-Smith, 1984). In Egypt, the success of wheat cultivars to be cultivated in the rainfed area of the northern coast, may depend entirely on the earliness of these genotypes which enables them to escape from drought that might occur late in the season.

Heading date in wheat is an easily identifiable character that can be modified through selection (Allard and Harding, 1963; Avey et al., 1982; Frederickson and Kronstad, 1985 and May and Fan Sanford, 1992). Early flowering genotypes of cereal crops grow more successfully under water stress conditions than late flowering genotypes (Blum, 1970; Alessi and Power, 1976; Blum et al., 1977 and Fischer \& Maurer, 1978). Derara et al. (1969), Mahdy (1988) and Tahara et al. (1990) they found a negative correlation between grain yield and late maturity in wheat.

The aim of this work is to: 1study the effect of two cycles of direct selection for heading date, 2- determine the effect of selection for early heading on yield and its components.

\section{Materials and Methods}

The breeding materials used in this study consisted of $80 \mathrm{~F}_{\mathbf{3}}$-families traced back to a random sample from F2 single plants originated from a cross between Bani Sweif 1/3/STJ3 and Bani Sweif 1/3/LKS4 lines. The families and the parents were grown in 2009/2010 season at Sids, Bani Sweif, Res Sta. in a randomized complete block design of three replications. Each plot was single row $3 \mathrm{~m}$ long, $30 \mathrm{~cm}$ apart and $5 \mathrm{~cm}$ between grains within row. The cultural practices were carried out as recommended for wheat production.

Heading date was recorded on plot mean basis as days from planting to the day when $50 \%$ of the heads protruded from the flag leaf-sheath. The earliest head of each plot was labeled. At maturity, individual plant data were recorded on twenty random plants from the middle of each plot. The following traits were recorded on each plant, i.e. plant height $(\mathrm{PH})$, number of spikes/plant $(\mathrm{S} / \mathrm{P})$, no. of kernels/spike $(\mathrm{K} / \mathrm{S})$, grain yield/plant (GY) and 100 kernel weight (KW) determined on plot mean basis. The earliest plant from each of the earliest 20 families were selected $\left(\mathrm{C}_{2}\right)$.

In 2010/2011 season, the bulk sample $\left(\mathrm{C}_{0}\right)$, parents, and the selected families $\left(C_{1}\right)$ were evaluated for earliness, grain yield and its components. The earliest plant from the earliest 10 families were selected $\left(\mathrm{C}_{2}\right)$.

In 2011/2012 season, the bulk sample, parents and the selected families $\left(C_{2}\right)$ were evaluated for earliness, grain yield and its components.

Data were subjected to analysis of variance on plot mean basis. The heritability in broad sense was estimated as the ratio of genotypic $\left(\sigma_{G}^{2}\right)$ to the phenotypic $\left(\sigma_{\mathbf{P}}^{2}\right)\left(\sigma^{2} \mathrm{e} / \mathrm{r}+\sigma^{2} \mathrm{~g}\right)$ variance according to Walker (1960). Genotypic variance was computed from the expected mean squares from the analysis of variances. The geno- 
typic $(\mathrm{GCV} \%)$ and phenotypic (PCV\%) coefficients of variability were calculated as $\sigma_{\mathrm{g} / \overline{\mathrm{x}}} \times 100$ and $\sigma_{\mathrm{p} / \overline{\mathrm{x}}} \times 100$, respectively. Phenotypic and genotypic variances, coveriances and correlations were calculated on plot mean basis as outlined by AlJibouri et al. (1958). Realized heritability $\left(\mathrm{h}^{2}\right)$ was calculated as $\mathrm{h}^{2}=\mathrm{R} / \mathrm{S}$ (Falconer, 1989), where $\mathrm{R}=$ response to selection and $\mathrm{S}=$ selection differential. Significancy of the observed response was calculated by using Rev. L.S.D.

\section{Results and Discussion}

1- Description of the base population ( $F_{3}$-geneation, season 2009 / 2010):

\section{1- Means and variance:}

The analyses of variance (Table 1) indicate significant differences among $\mathrm{F}_{3}$ families for heading date, plant height, spikes/plant, 100-kernel weight and grain yield/plant. Estimates of the phenotypic and genotypic coefficients of variation indicate the presence of sufficient variability for all the studied traits. The obtained variability suggest that selection among the $\mathrm{F}_{3}$-families may produce changes in this population. Estimates of broad sense heritability were high for the studied traits. Estimates of bread sense heritability at one locations in one year were biased upward due to confounding the effects of locations and years with the genetic variance estimates (O'Brien et al., 1978). In general, high estimates of broad sense heritabilities (Table 1) indicate that the environmental effects were small compared to the genetic effects.

The average number of days to heading of $\mathrm{P}_{1}$ was 100.0 compared to
91.6 days for $\mathrm{P}_{2}$ with $\mathrm{F} 3$-families mean of 105.98 days. Days to heading showed over-dominance towards lateness. The phenotypic (PCV\%) and genotypic $(\mathrm{GCV} \%)$ coefficients of variation for days to heading were 6.23 and $4.71 \%$, respectively. Such magnitude of variability could be considered sufficient for selection for early heading.

The average no. of spikes/plant of $\mathrm{P}_{1}$ was 4.67 compared to 6.00 for $\mathrm{P}_{2}$ with $\mathrm{F}_{3}$-families mean of 6.03 . Number of spikes/plant of the $\mathrm{F}_{3^{-}}$ families, tended to show complete dominance towards the higher parent. The phenotypic (PCV\%) and genotypic (GCV\%) coefficients of variation for this trait were 33.99 and $30.21 \%$, respectively. These results are in agreement with those reported by Kheiralla et al. (2004), Mahdy (2007) and Mahdy (2012).

Plant height of $\mathrm{P}_{1}$ was 90.0 compared to $88.3 \mathrm{~cm}$ for $\mathrm{P}_{2}$ with $\mathrm{F}_{3}$ population average of $98.45 \mathrm{~cm}(\mathrm{Ta}-$ ble 1). Plant height showed over dominance towards tallness. The genetic coefficient of variation $(\mathrm{GCV} \%)$ in plant height reached $7.72 \%$.

The average number of grains/spike was higher for $\mathrm{P}_{2}$ than $P_{1}$. Number of grains/spike of $P_{1}$ was 73.3 compared to 81.6 for $\mathrm{P}_{2}$. This could be due to the difference in spike length. The phenotypic (PCV\%) and genotypic $(\mathrm{GCV} \%)$ coefficient of variations for number of grains/spike were 18.55 and $18.09 \%$ for $\mathrm{P}_{1}$ and $\mathrm{P}_{2}$, respectively. $\mathrm{P}_{1}$ had high 100 -grain wheat (Table 3 ) compared to $\mathrm{P}_{2}$. The $\mathrm{F}_{3}$-families tended to show over dominance towards the lower grain weight parent. 
The average grain yield/plant was larger for $\mathrm{P}_{\mathbf{1}}$ than $\mathrm{P}_{\mathbf{2}}$. Grain yield/plant of $\mathrm{P}_{1}$ was 32.35 compared to $30.53 \mathrm{gm}$ for $\mathrm{P}_{\mathbf{2}}$. $\mathrm{F}_{\mathbf{3}}$-families (34.14 $\mathrm{m})$ tended to show over dominance towards the highest grain yield parent. The phenotypic (PCV\%) and genotypic $(\mathrm{GCV} \%)$ coefficient of variations for grain yield/plant were 26.12 and $25.74 \%$, respectively. This indicates that selection of grain yield may increase grain yield/plant.

\section{2- Phenotypic and genotypic correlations:}

Phenotypic and genotypic correlation coefficients among all possible pairs of the studied traits in $\mathrm{F}_{\mathbf{3}}$ population are presented in Table (2). The improvement of one character by selection frequently causes simultaneous changes in other characters. The effect is the result of correlations between characters, which may be genetic or environmental in nature. Genetic correlations arise from pleitropy, linkage between loci controlling the characters or from random genetic drift (Tomas et al., 1994). According to Simminds (1979) and Falconer (1989), pleitropy is the chief cause of genetic correlations, while Mather and Jinks (1982) have argued that linkages are the more likely explanation.

Results in Table (2) indicated negative and low phenotypic correlations between heading date and each of No. of spikes/plant (-0.32), No. of kernels/ spike (-0.01), 100-kernel weight (-0.06) and grain yield/plant ($0.43)$. While genotypic correlation values were $-0.41,-0.08,-0.12$ and 0.34 between heading date and each of the above mentioned traits, respectively, indicating that selection for earliness may decrease any of these traits in these materials. These results are in general agreement with those reported by Wells and Kofoid (1986) who found that the genotypic correlation value among heading date and grain yield was negative.

Table 1. Means, mean squares, phenotypic (P.C.V. \%) and genotypic (G.C.V. \%) coefficients of variability and heritability values for the studied traits in the $F_{3}$ families.

\begin{tabular}{|c|c|c|c|c|c|c|c|c|c|}
\hline \multirow{2}{*}{ Trait } & \multicolumn{3}{|c|}{ Mean } & \multicolumn{3}{|c|}{ Mean squares } & \multirow{2}{*}{$\begin{array}{c}\text { P.C.V } \\
\%\end{array}$} & \multirow{2}{*}{$\begin{array}{c}\text { G.C.V } \\
\%\end{array}$} & \multirow{2}{*}{$\mathbf{h}^{2}$} \\
\hline & $F_{3}$ families & $\mathbf{P}_{1}$ & $\mathbf{P}_{2}$ & Reps. & Families & Error & & & \\
\hline Heading & 105.98 & 100 & 91.6 & 34.25 & $93.67 * *$ & 18.79 & 6.25 & 4.71 & 57.05 \\
\hline Plant $h$ & & 90.0 & 88.3 & 7.529 & & 18.05 & 8.84 & 7.72 & 76.17 \\
\hline No. of & & 4.67 & 6.0 & 1.679 & & 0.882 & 33.99 & 30.21 & 79.00 \\
\hline No. of kernels/ spike & & 73.3 & 81.6 & 15.52 & $411.09 * *$ & 6.901 & 18.55 & 18.09 & 95.13 \\
\hline 100-kernel weight & 3.551 & 5.31 & 5.104 & 0.031 & $1.791 * *$ & 0.031 & 22.13 & 21.57 & 94.98 \\
\hline Grain yield/plant & 34.14 & 32.35 & 30.53 & 0.657 & $207.31 * *$ & 3.035 & 26.12 & 25.74 & 87.11 \\
\hline
\end{tabular}

Table 2. Phenotypic correlation (above diagonal) and genotypic correlation (below diagonal) values estimated from the $F_{3}$ families.

\begin{tabular}{|l|c|c|c|c|c|c|}
\hline \multicolumn{1}{|c|}{ Trait } & $\begin{array}{c}\text { Heading } \\
\text { date }\end{array}$ & Plant height & $\begin{array}{c}\text { No. of } \\
\text { spikes/plant }\end{array}$ & $\begin{array}{c}\text { No. of ker- } \\
\text { nels/ spike }\end{array}$ & $\begin{array}{c}\text { 100-kernel } \\
\text { weight }\end{array}$ & $\begin{array}{c}\text { Grain yield/ } \\
\text { plant }\end{array}$ \\
\hline Heading date & - & 0.165 & -0.318 & -0.008 & -0.055 & -0.43 \\
\hline Plant height & 0.057 & - & 0.232 & 0.099 & 0.054 & 0.21 \\
\hline No. of spikes/plant & -0.414 & 0.236 & - & 0.029 & 0.170 & 0.679 \\
\hline No. of kernels/spike & -0.081 & 0.098 & 0.040 & - & 0.042 & 0.110 \\
\hline 100-kernel weight & -0.124 & 0.034 & 0.209 & 0.016 & - & 0.173 \\
\hline Grain yield/plant & -0.34 & 0.010 & 0.811 & 0.120 & 0.180 & - \\
\hline
\end{tabular}


Low and positive genotypic correlations were obtained between plant height and each of No. of spikes/plant (0.23), 100-kernel weight (0.034), grain yield/plant $(0.01)$, heading date $(-0.057)$ and No. of kernels/ spike (0.01) while phenotypic correlation values were $0.23,0.05,0.21,0.16$ and 0.10 between plant height and each of the above mentioned traits in durum wheat, respectively.

Results of the base population for both the phenotypic and genotypic correlation coefficients among No. of spikes/plant and the other studied traits are presented in Table (2). The data showed that No. of spikes/plant exhibited low and positive phenotypic correlation with each of plant height (0.23), No. of kernels/spike (0.03) and 100-kernel weight (0.17), while it was high and positive with grain yield/plant (0.68). The results of genotypic correlation indicated low and positive values between No. of spikes/plant and each of No. of kernels/spike (0.04) and 100-kernel weight (0.21), but it was high and positive with grain yield/plant $(0.81)$. This indicates that selection for no. of spikes/plant may increase grain yield/plant.

The results of phenotypic and genotypic correlations between No. of kernels/spike and other studied traits for the base population, showed low and positive phenotypic and genotypic correlations values, while the phenotypic and genotypic correlated values between no. of kernels/spike and grain yield (0.11 and 0.12$)$, respectively.

The phenotypic and genotypic correlations values between grain yield and 100-kernel weight were low and positive $(0.17$ and 0.18$)$, respectively.

\section{2- Response to selection for early heading:}

2.1- Variability, phenotypic (P.C.V.\%), genotypic (G.C.V.\%) coefficient of variations and heritability:

The mean squares of the selected families for early heading after cycle 1 and cycle 2 of selection in the $\mathrm{F}_{4}$ and $\mathrm{F}_{5}$ generations are shown in Table (3). The results indicated highly significant differences among families. The results also indicated that phenotype and genotype coefficients of variability for days to heading in $\mathrm{F}_{4}\left(\mathrm{C}_{1}\right)$ were 3.66 and $2.10 \%$ while they were 3.04 and $2.01 \%$ for $\mathrm{F}_{5}\left(\mathrm{C}_{2}\right)$ selected families (Table 4).

Table 3. The analysis of variance of early heading for early selected families of $\mathrm{F}_{4}$ $\left(C_{1}\right)$ and $F_{5}\left(C_{2}\right)$ generations in $2010 / 2011$ and 2011/2012 seasons.

\begin{tabular}{|c|l|c|c|}
\hline \multirow{2}{*}{ Gen. } & \multicolumn{1}{|c|}{ S.O.V. } & d.f & Mean squares \\
\hline \multirow{3}{*}{ F $_{\mathbf{4}}$} & Rep. & $\mathbf{2}$ & 13.97 \\
\cline { 2 - 4 } & Genotype & $\mathbf{2 2}$ & $27.05^{* *}$ \\
\cline { 2 - 4 } & Error & $\mathbf{4 4}$ & 8.23 \\
\hline \multirow{3}{*}{ F $_{5}$} & Rep. & $\mathbf{2}$ & 5.840 \\
\cline { 2 - 4 } & Genotype & $\mathbf{1 2}$ & $40.85^{* *}$ \\
\cline { 2 - 4 } & Error & $\mathbf{2 4}$ & 3.54 \\
\hline
\end{tabular}

** Significant at 0.01 level of probability. 
The results showed small differences between P.C.V. and G.C.V.\% for all generations, indicating the importance of genetic effects in controlling the inheritance of days to heading. Meanwhile, the phenotypic and genotypic variations as indicated by P.C.V.\% and G.C.V.\% decreased after two cycles of selection and the genetic variation for earliness was exhausted, so, the selection for this trait may not be effective in the following generations. These results are in agreement with the findings of Busch and Kofoid (1982) who found, in spring wheat, that the genotypic variances for heading date were 1.75 and 2.10 in the first and second cycles of recurrent selection, respectively. Kheiralla et al. (1993) studied, in bread wheat, the effect of two cycles of direct selection on heading date and reported that P.C.V.\% and G.C.V.\% were (3.94 and 3.70), (1.44 and $1.17 \%$ ) and (1.46 and $1.04 \%)$ for $\mathrm{C}_{0}, \mathrm{C}_{1}$ and $\mathrm{C}_{2}$ cycles, respectively, indicating that $\mathrm{C}_{0}$ and $\mathrm{C}_{1}$ families possessed considerable amount of genetic variability more than the $\mathrm{C}_{2}$ families for days to heading. Mahdy et al. (1996) found that phenotypic and genotypic coefficients of variation for days to heading in durum wheat were $(7.19$ and $6.63 \%)$ and (4.08 and 3.46\%) in the $\mathrm{C}_{1}$ and $\mathrm{C}_{2}$, respectively. Attia (2003), in wheat, reported that p.c.v. $\%$ and g.c.v. $\%$ for days to heading were $(5.15$ and $4.85 \%)$ for $\mathrm{F}_{3}$ families and (4.74 and $4.55 \%$ ) for $\mathrm{F}_{4}$ families under normal and drought conditions, respectively.

The realized heritability for $\mathrm{F}_{4}$ was $51.14 \%$, Table (4) and for $\mathrm{F}_{5}$ selected families it was $49.40 \%$. It is of interest to note that heritability estimates were decreased from the $\mathrm{F}_{4}$ to the $\mathrm{F}_{5}$ generation for days to heading. This could be due to the increase in the experimental error, in other words, the environmental variation as the homozygozity of the lines, which maximized the phenotypic relative to the genotypic variance.

Similar results were obtained by Kheiralla et al. (1993) who found, in bread wheat, that estimates of heritability for days to heading were 88,67 and $49 \%$ for $C_{0}, C_{1}$ and $C_{2}$ cycles of selection, respectively. Also, Ismail (1995) reported that estimates of heritability in broad sense were 87,70 and $51 \%$ for $\mathrm{F}_{3}$ bulk $\left(\mathrm{C}_{0}\right), \mathrm{F}_{4}$ families $\left(\mathrm{C}_{1}\right)$ and $\mathrm{F}_{5}$ families $\left(\mathrm{C}_{2}\right)$, respectively.

The efficiency of selection procedure for decreasing days to heading as the deviation percentage from the bulk sample and the earlier parent are presented in Table (4). The results showed that direct selection for early heading decreased the efficiency by (7.00 and $1.44 \%$ ) for $\mathrm{F}_{4}$ selected families (cycle 1) and by (7.45 and $3.53 \%$ ) for $\mathrm{F}_{5}$ selected families (cycle 2) from the bulk sample and the early parent, respectively. These results agree with other studies on response to selection for early heading date (Avey et al., 1982; Frederickson and Kronstand, 1985; Mahdy, 1988; Younis et al., 1988; May and Fan Sanford, 1992; Kheiralla et al., 1993; Zakaria et al., 2008; Ali, 2011; Mahdy et al., 2012a and Mahdy, R. 2012, in which they reported that earliness could be improved by selection for days to heading, in bread wheat. 
2.2- Means and direct observed gain in days to heading:

Means of the early heading selected families in the $\mathrm{F}_{5}$-generation after two cycles of selection are shown in Table (6). Days to heading varied from 87.33 for family no. 29 to 94.33 days for family no. 50 with an average of 91.00 days after the second cycle of selection for earliness.

The observed direct response in percentage from the bulk sample and earlier parent for the selected families for days to heading are presented in Tables (7 and 8). All of the ten early selected families were earlier than the bulk sample $(\mathrm{P}<0.01)$. The direct response to selection for days to heading ranged from -4.00 to $-11.00 \%$ from the bulk sample. Meanwhile, five out of the ten early selected families were significant or highly significant earlier than the earliest parent.

\section{3-Means and correlated re- sponse of traits for early selected families:}

The analysis of variance for the correlated traits to earliness selected $\mathrm{F}_{5}$ families (Table 5) indicated highly signification differences among genotypes for to studied traits.

Direct selection for early heading was accompanied by decrease of $2.17,3.76$, and $1.39 \%$ for plant height, no. of kernels/spike and grain yield/plant, respectively, after two cycles of selection compared to the bulk sample (Table 7). Such decrease was accompanied with highly significant decrease in plant height by $10.67 \%$ for Fam. No. 50. These results revealed that selection for earliness highly significant decreased no. of kernels/spike by 5.33, 5.66, 7.66,
8.00 and $9.66 \%$ for family no. 54,76 , 77, 68 and 50, respectively. The results for 100-grain weight indicate that 3 and 4 families out of ten were significant and highly significant less than the bulk sample.

Direct selection for early heading significantly decreased grain yield/ plant by $1.75,1.87,1.89,2.64$, 5.16 and $6.42 \%$ for family no. 54,66 , 76, 77, 68 and 50, respectively. One promising family (Family no. 29) was earlier than the bulk sample and surpassed it in plant height, no. of kernels/spike, 100 grain weight and grain yield/plant by $11.00,2.33,4.00$, 1.07 and $2.32 \%$, respectively, (Table 7).

Direct selection for early heading was accompanied by an average decrease of $3.17,3.76$ and $1.95 \%$ for plant height, no. of kernels/ spike and grain yield/plant, respectively, after two cycles of selection compared to the earliest parent (Table 8). These results revealed that the family no. 50 was significantly decreased by $11.67 \%$ in plant height compared with the earlier parent. These results indicated that the decrease in early heading was significantly accompanied by decrease in no. of kernels/spike by $5.33,5.66,7.66,8.00$ and $9.66 \%$ for families no. 54, 76, 77, 68 and 50, respectively. Five out of the ten early selected families were significantly heavier in 100-kernels weight.

Direct selection for early heading significantly reduced grain yield/ plant by $2.31,2.45,3.20,5.72$ and $6.98 \%$ for family no. 54, 76, 77, 68 and 50, respectively. It should be indicated to the promising family no. 29 which was significantly increased 
in no. of kernels/spike, 100-grain weight and grain yield/plant compared with the best parent. These results are in agreement with Kheiralla (1993), Ismail (1995), Mahdy et al. (1996), Talbert et al. (2001), Mobarek (2007), El-Morshidy et al. (2010), Ali (2011) and Mahdy et al. (2012b) and Mahdy, R. (2012) who reported that earliness could be improved by selection for days to heading. Otherwise, they noted that improving earliness was accompanied with adverse effects on yield and other correlated traits.

Table 4. Mean, phenotypic (P.C.V.\%), genotypic (G.C.V.\%) coefficient of variability, realized heritability $\left(\mathrm{h}^{2}\right)$ and realized gain for early selected families in $\mathrm{C}_{1}$ ( $F_{4}$-generation) and $C_{2}\left(F_{5}\right.$-generation $)$

\begin{tabular}{|c|c|c|c|c|c|c|c|c|c|}
\hline \multirow{3}{*}{ Cycle } & \multicolumn{4}{|c|}{ Mean } & \multirow{3}{*}{$\begin{array}{l}\text { P.C.V. } \\
\%\end{array}$} & \multirow{3}{*}{$\begin{array}{l}\text { G.C.V. } \\
\%\end{array}$} & \multirow{3}{*}{$\mathbf{h}^{2}$} & \multirow{2}{*}{\multicolumn{2}{|c|}{$\begin{array}{l}\text { Realized gain } \\
\text { from: }\end{array}$}} \\
\hline & \multirow[b]{2}{*}{$\mathbf{P}_{1}$} & \multirow[b]{2}{*}{$\mathbf{P}_{2}$} & \multirow{2}{*}{$\begin{array}{l}\text { Selected } \\
\text { families }\end{array}$} & \multirow[b]{2}{*}{$\begin{array}{c}\text { Bulk } \\
\text { sample }\end{array}$} & & & & & \\
\hline & & & & & & & & Bulk & $\begin{array}{c}\text { The early } \\
\text { parent }\end{array}$ \\
\hline $\mathrm{C}_{1}\left(\mathrm{~F}_{4}\right)$ & 96.33 & 93.90 & 92.55 & 99.50 & 3.66 & 2.10 & 51.14 & 7.00 & 1.44 \\
\hline $\mathrm{C}_{2}\left(\mathrm{~F}_{5}\right)$ & 96.66 & 94.33 & 91.00 & 98.33 & 3.04 & 2.01 & 49.30 & 7.45 & 3.53 \\
\hline
\end{tabular}

Table 5. The analysis of variance for the correlated traits to selected $F_{5}$ families in 2011/2012.

\begin{tabular}{|c|c|c|c|c|c|}
\hline \multirow{3}{*}{ S.O.V. } & \multirow{3}{*}{ d.f } & \multicolumn{4}{|c|}{ Mean square } \\
\hline & & \multicolumn{4}{|c|}{ Correlated traits to earliness selected families } \\
\hline & & PH & $\begin{array}{l}\text { No. of Ker- } \\
\text { nels/sp }\end{array}$ & $100 \mathrm{Kw}$ & GY/P \\
\hline Rep. & 2 & 2.154 & 9.564 & 0.014 & 0.54 \\
\hline Genotype & 12 & $73.29 * *$ & $343.06^{* *}$ & $2.717 * *$ & $245.67^{* *}$ \\
\hline Error & 24 & 16.876 & 6.98 & 0.02 & 1.23 \\
\hline
\end{tabular}

Table 6. Means of selected families for early heading in $F_{5}$ generation and correlated traits in season 2011/2012.

\begin{tabular}{|c|c|c|c|c|c|}
\hline \multirow[b]{2}{*}{$\begin{array}{l}\text { Fam. } \\
\text { No. }\end{array}$} & \multirow{2}{*}{$\begin{array}{r}\text { Criterion of } \\
\text { selection HD }\end{array}$} & \multicolumn{4}{|c|}{ Correlated traits } \\
\hline & & PH & $\begin{array}{l}\text { No. of ker- } \\
\text { nel/ sp. }\end{array}$ & $100 \mathrm{GW}$ & GY/P \\
\hline 27 & 90.67 & 95.00 & 79.33 & 5.20 & 41.09 \\
\hline 29 & 87.33 & 98.00 & 86.33 & 6.20 & 44.10 \\
\hline 40 & 88.67 & 96.67 & 80.67 & 5.86 & 42.71 \\
\hline 50 & 94.33 & 85.00 & 72.67 & 4.41 & 35.36 \\
\hline 54 & 91.67 & 95.00 & 77.00 & 5.14 & 40.03 \\
\hline 65 & 89.33 & 96.33 & 79.67 & 5.34 & 41.30 \\
\hline 66 & 88.33 & 97.33 & 84.33 & 5.94 & 43.65 \\
\hline 68 & 93.67 & 90.00 & 74.33 & 4.89 & 36.62 \\
\hline 76 & 92.67 & 91.67 & 76.67 & 5.12 & 39.89 \\
\hline 77 & 93.33 & 90.00 & 74.67 & 4.90 & 39.14 \\
\hline Average & 91.00 & 93.50 & 78.60 & 5.30 & 40.40 \\
\hline Bulk & 98.33 & 95.67 & 82.33 & 5.13 & 41.78 \\
\hline $\mathbf{P}_{1}$ & 96.66 & 96.67 & 77.67 & 5.04 & 40.67 \\
\hline $\mathbf{P}_{2}$ & 94.33 & 91.67 & 82.33 & 4.67 & 42.34 \\
\hline \begin{tabular}{l|l|} 
Rev. & $\mathbf{5 \%}$ \\
\end{tabular} & 2.90 & 7.14 & 3.86 & 0.20 & 1.62 \\
\hline
\end{tabular}




\begin{tabular}{|l|l|l|l|l|l|l|}
\hline LSD & $\mathbf{1 \%}$ & 3.90 & 9.76 & 5.13 & 0.26 & 2.16 \\
\hline
\end{tabular}

Table 7. The observed direct gain and correlated response as percentage from the bulk sample of the early heading selected families in the $F_{5}$ generation.

\begin{tabular}{|c|c|c|c|c|c|}
\hline \multirow{2}{*}{$\begin{array}{c}\text { Fam. } \\
\text { No. }\end{array}$} & \multirow{2}{*}{$\begin{array}{c}\text { Criterion of } \\
\text { selection HD }\end{array}$} & \multirow{2}{*}{$\mathbf{P H}(\mathbf{c m})$} & $\begin{array}{c}\text { Co. of } \\
\text { kernel/ sp. }\end{array}$ & $\begin{array}{c}\mathbf{1 0 0} \mathbf{G W} \\
\mathbf{( g m})\end{array}$ & \multirow{G}{*}{$\mathbf{G} / \mathbf{P} \mathbf{( g m})$} \\
\hline $\mathbf{2 7}$ & $-7.66^{* *}$ & -0.67 & -3.00 & 0.07 & -0.69 \\
\hline $\mathbf{2 9}$ & $-11.00^{*}$ & 2.33 & $4.00^{*}$ & $1.07^{* *}$ & $2.32^{* *}$ \\
\hline $\mathbf{4 0}$ & $-9.66^{* *}$ & 1.00 & -1.66 & $0.73^{* *}$ & 0.93 \\
\hline $\mathbf{5 0}$ & $-4.00^{* *}$ & $-10.67^{* *}$ & $-9.66^{* *}$ & $-0.72^{* *}$ & $-6.42^{* *}$ \\
\hline $\mathbf{5 4}$ & $-6.66^{* *}$ & -0.67 & $-5.33^{* *}$ & 0.01 & $-1.75^{*}$ \\
\hline $\mathbf{6 5}$ & $-9.00^{* *}$ & 0.66 & -2.66 & $0.21^{*}$ & -0.48 \\
\hline $\mathbf{6 6}$ & $-10.00^{* *}$ & 1.66 & 2.00 & $0.81^{* *}$ & $1.87^{*}$ \\
\hline $\mathbf{6 8}$ & $-4.66^{* *}$ & -5.67 & $-8.00^{* *}$ & $-0.24^{*}$ & $-5.16^{* *}$ \\
\hline $\mathbf{7 6}$ & $-5.66^{* *}$ & -4.00 & $-5.66^{* *}$ & -0.01 & $-1.89^{*}$ \\
\hline $\mathbf{7 7}$ & $-5.00^{*}$ & -5.67 & $-7.66^{* *}$ & $-0.23^{*}$ & $-2.64^{* *}$ \\
\hline Average & $-\mathbf{7 . 3 3}$ & $\mathbf{- 2 . 1 7}$ & $\mathbf{- 3 . 7 6}$ & $\mathbf{0 . 1 7}$ & $\mathbf{- 1 . 3 9}$ \\
\hline
\end{tabular}

* and ** Significant at 0.05 and 0.01 levels of probability, respectively.

Table 8. The observed direct gain and correlated response as percentage from the best parent sample of the early heading selected families in the $F_{5}$ generation.

\begin{tabular}{|c|c|c|c|c|c|}
\hline \multirow{2}{*}{$\begin{array}{c}\text { Fam. } \\
\text { No. }\end{array}$} & \multirow{2}{*}{$\begin{array}{c}\text { Criterion of } \\
\text { selection HD }\end{array}$} & \multirow{2}{*}{ PH (cm) } & $\begin{array}{c}\text { No. of } \\
\text { kernel/ sp. }\end{array}$ & $\begin{array}{c}\mathbf{1 0 0} \mathbf{G W} \\
\mathbf{( g m})\end{array}$ & GY/P (gm) \\
\hline $\mathbf{2 7}$ & $-3.66^{*}$ & -1.67 & -3.00 & 0.16 & -1.25 \\
\hline $\mathbf{2 9}$ & $-7.00^{* *}$ & 1.33 & $4.00^{*}$ & $1.16^{* *}$ & $1.76^{*}$ \\
\hline $\mathbf{4 0}$ & $-5.66^{* *}$ & 0.00 & -1.66 & $0.82^{* *}$ & 0.36 \\
\hline $\mathbf{5 0}$ & $0.00 \mathrm{~ns}$ & $-11.67^{* *}$ & $-9.66^{* *}$ & $-0.63^{* *}$ & $-6.98^{* *}$ \\
\hline $\mathbf{5 4}$ & $-2.66 \mathrm{~ns}$ & -1.67 & $-5.33^{* *}$ & 0.10 & $-2.31^{* *}$ \\
\hline $\mathbf{6 5}$ & $-5.00^{* *}$ & -0.34 & -2.66 & $0.30^{* *}$ & -1.04 \\
\hline $\mathbf{6 6}$ & $-6.00^{* *}$ & 0.66 & 2.00 & $0.90^{* *}$ & 1.31 \\
\hline $\mathbf{6 8}$ & $-0.66 \mathrm{~ns}$ & -6.67 & $-8.00^{* *}$ & -0.15 & $-5.72^{* *}$ \\
\hline $\mathbf{7 6}$ & $-1.66 \mathrm{~ns}$ & -5.00 & $-5.66^{* *}$ & 0.08 & $-2.45^{* *}$ \\
\hline $\mathbf{7 7}$ & $-1.00 \mathrm{~ns}$ & -6.67 & $-7.66^{* *}$ & -0.14 & $-3.20^{* *}$ \\
\hline Average & $\mathbf{- 3 . 5 3}$ & $\mathbf{- 3 . 1 7}$ & $\mathbf{- 3 . 7 6}$ & $\mathbf{0 . 2 6} *$ & $-\mathbf{1 . 9 5}$ \\
\hline
\end{tabular}

$*$ and $* *$ Significant at 0.05 and 0.01 levels of probability, respectively.

\section{References}

Alessi, J. and J.F. Power. 1976. Water use dryland corn as affected by maturity class and plant spacing. Agron. J. 68: 547-550.

Ali, M.A. 2011. Response to pedigree selection for earliness and grain yield in spring wheat under heat stress. Asian J. Crop Sci., 3: 118129.
Al-Jibouri, H.A., P.A. Miller and H.F. Robinson. 1958. Genotypic and environmental variance and covariances in an upland cotton cross of interspecific origin. Agron. J., 50: 633-636.

Allard, R.W. and J. Harding. 1963. Early generation analysis and prediction of gain under selection in deriva- 
tives of a wheat hybrid. Crop Sci., 3: 454-456.

Attia, I.A. 2003. Selection for drought tolerance in wheat. Ph.D. Thesis, El-Minia Univ., Egypt.

Avey, D.P., H.W. Ohm, F.L. Patterson and W.E. Nyquist. 1982. Three cycles of simple recurrent selection for early heading in winter wheat. Crop Sci., 22: 908-912.

Blum, A. 1970. Effect of plant density and growth duration on grain sorghum yield under limited water supply. Agron. J., 62: 333-336.

Blum, A.; G.F. Arkin and W.R. Jordan. 1977. Sorghum root morphogenesis and growth. 1- Effect of maturity genes. Crop Sci., 17: 149-153.

Busch, R.H. and K. Kofoid. 1982. Recurrent selection for kernel weight in spring wheat. Crop Sci., 22: 568-572.

Clark, J.M. and T.F. Townley-Smith. 1984. Screening and selection techniques for improving drought resistance. In Crop Breeding. (Ed. P.B. Vose and S.G. Blixt) pp. 137162. (Pergamon Press).

Derara, N.F.; D.R. Marshall and L.N. Balaam. 1969. Genetic variability in root development in relation to drought tolerance in spring wheat. Expt. Agric., 5: 327-337.

El-Morshidy, M.A., K.A. Kheiralla, M.A. Ali and A.A. Said. 2010. Response to selection for earliness and grain yield in wheat (Triticum aestivum L.) under normal and water stress conditions. Assiut J. Agric. Sci., 41: 1-23.

Falconer, D.S. 1989. Introduction to Quantitative Genetics. $3^{\text {rd }}$ ed. Longman, Hong Kong, pp 438.

Fischer, K.S. and R. Maurer. 1978. Drought resistance in spring wheat cultivars. 1- Grain yield response. Aust. J. Agric. Res., 29: 897-912.

Frederickson, L.J. and W.E. Kronstad. 1985. A comparison of intermating and selfing following selection for heading date in two diverse winter wheat crosses. Crop Sci., 25: 555560.

Ismail, A.A. 1995. Pedigree selection for grain yield, grain weight and earliness in two segregating populations of spring wheat. Assiut J. Agric. Sci., 26(4): 59-72.

Kheiralla, K.A. 1993. Selection response for grain yield and its components in a segregating population of spring wheat. Assiut J. Agric. Sci., 24: 87-98.

Kheiralla, K.A., E.E. Mahdy and R.A. Dawood. 1993. Selection for early heading and correlated response in grain yield and its components of spring wheat. Assiut J. Agric. Sci., 24 (4): 95-106.

Kheiralla, K.A.; M.A. El-Morshidy; M.H. Motawea and A.A. Saedid. 2004. Performance and stability of some wheat genotypes under normal and water stress conditions. Assiut J. Agric. Sci., 35: 74-94.

Mahdy, E.E. 1988. Single and multiple traits selection in a segregating population of wheat, Triticum aestivum L. Pl. Breed., 101: 245-249.

Mahdy, E.E., A.A. Ismail and K.A. Kheiralla. 1996. The relative merits of selection index and pedigree selection in improving grain yield of spring wheat. Assiut J. Agric. Sci., 27 (3): 17-33.

Mahdy, E.E., A.E. El-Karamity, S.A. Mokadem and H.M. Fouad. 2012a. Selection for grain yield and its components in two segregating populations. Minia Int. Conf. Agric. Irrig. In the Nile Basin Coun., 26 $6^{\text {th }}-29^{\text {th }}$ March 2012, p. 595-604.

Mahdy, E.E.; A.E. El-Karamity; S.A. Mokadem and H.M. Fouad. 2012b. Selection for earliness in two segregating populations of bread wheat, Triticum aetivum L. Minia 
Int. Conf. Agric. Irrig. In the Nile Basin Coun., 26 $6^{\text {th }}-29^{\text {th }}$ March 2012, p. 605-614.

Mahdy, R.E.E. 2007. Inheritance of yield, yield components and drought tolerance traits in bread wheat (Triticum aestivum L.). M.Sc. Thesis, Fac. Agric. Assiut Univ. Agron. Dept. Egypt.

Mahdy, R.E.E. 2012. Response to selection for earliness and yield in bread wheat under normal and drought conditions. Ph.D. Thesis, Agron. Dept., Fac. Agric., Assiut Univ., Egypt.

Mather, K. and J.L. Jinks. 1982. Biometrical Genetics ( $3^{\text {rd }}$ ed.) Chapman and Hall London.

May, L. and D.A. Fan Sanford. 1992. Selection for early heading and correlated response in maturity of soft red winter wheat. Crop Sci., 32: 47-51.

Mobarek, M.Y.G. 2007. Efficiency of some breeding methodologies on some bread wheat populations under new valley conditions. Ph.D. Thesis, El-Minia Univ., Egypt.

O'Brien, L.; R.J. Baker and L.E. Evans. 1978. Response to selection for yield in $\mathrm{F}_{3}$ of four wheat crosses. Crop Sci., 18: 1029-1033.

Simminds, N.W. 1979. Principles of Crop Improvement. Longman Group, London.

Singh, G. and H. Chaudhary. 2006. Selection parameters and yield enhancement of wheat (Triticum aestivum L.) under different moisture stress condition. Asian J. Pl. Sci., 5: 894-898.

Tahara, M.; B.F. Carver; R.C. Johnson and E.L. Smith. 1990. Relationship between relative water content during reproductive development and winter wheat grain yield. Euphytica, 49: 255-262.

Talbert, L.E., S.P. Lanning, R.L. Murphy and J.M. Martin. 2001. Grain fill duration in twelve hard red spring wheat crosses: Genetic variation. Crop Sci., 41: 1390-1395.

Tomas, E.M.; M.J. Kearsey and M.A. Cornish. 1994. Correlated response to selection during selfing. Heredity, 73: 642-649.

Walker, T.T. 1960. The use of a selection index technique in the analysis of progeny row data. Emp. Cott. Gr. Rev., 37: 81-107.

Wells, W.C. and K.D. Kofoid. 1986. Selection indices to improve an intermating population of spring wheat. Crop Sci., 26: 1104-1109.

Younis, S.E.; M.K. Omara and M.Y. Hussein, 1988. A genetic analysis of earliness in wheat and the response to selection for flowering time under favorable clay soil and moisture stress conditions in sandy soils. Assiut J. of Agric. Sci., 9 (5): 35-47.

Zakaria, M.M.; M.A. El-Morshidy; K.A. Kheiralla and A.M. Tammam. 2008. Direct selection for grain yield and correlated response in bread wheat under normal and late sowing date. Assiut J. Agric. Sci., 39 (2): 1-16. 
الاتتخاب للتبكير والاستجابة المرتبطة في المحصول ومكوناته في قمح المكرونة

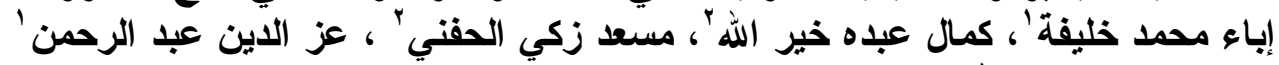

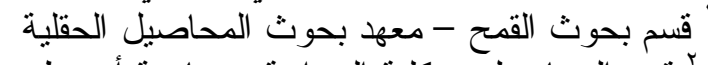

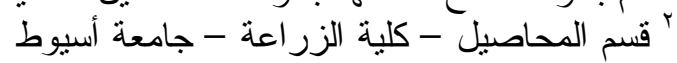

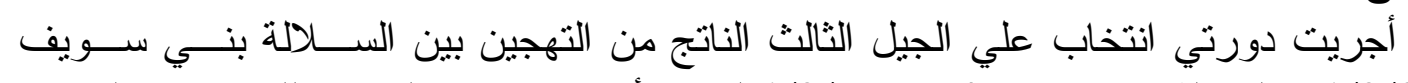

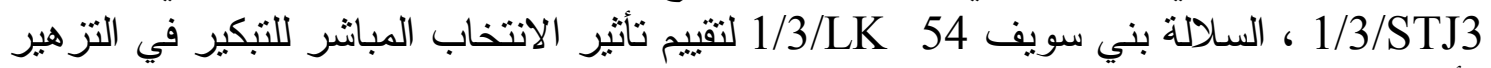

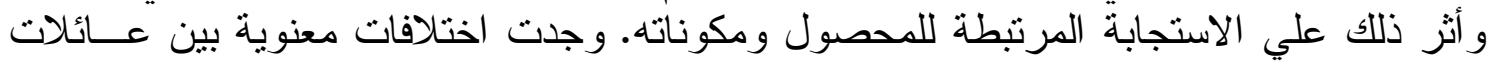

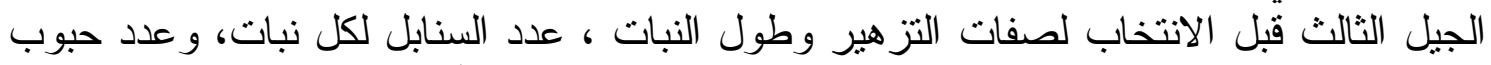

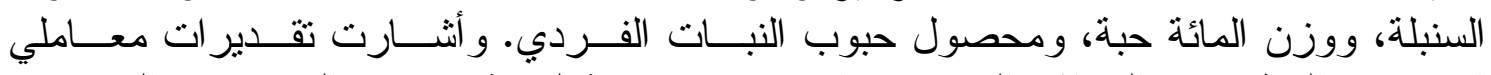

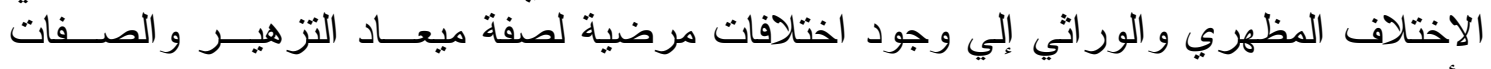

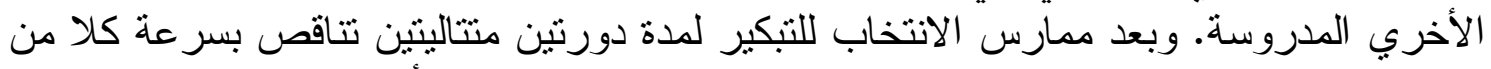

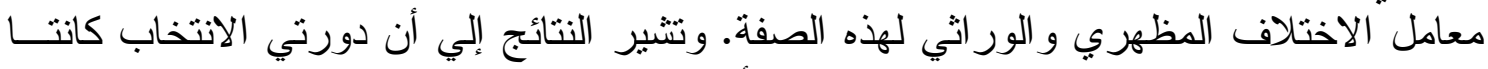

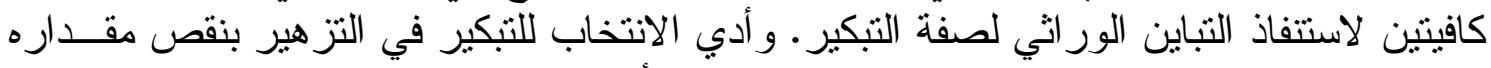

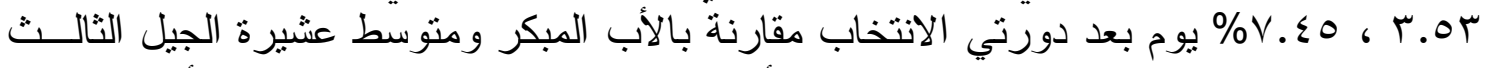

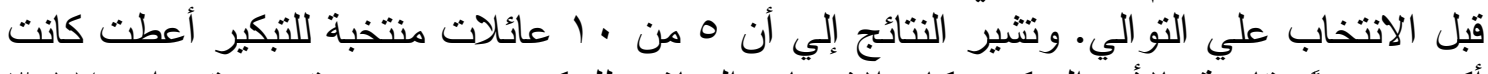

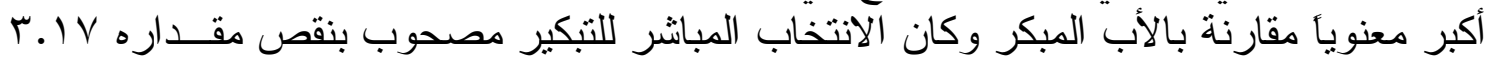

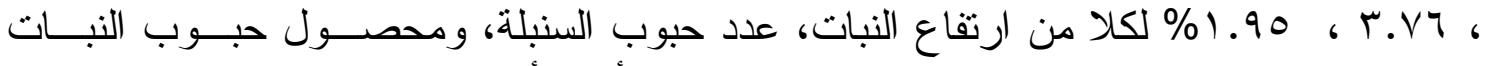

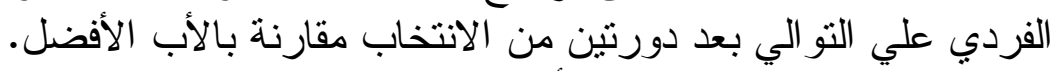

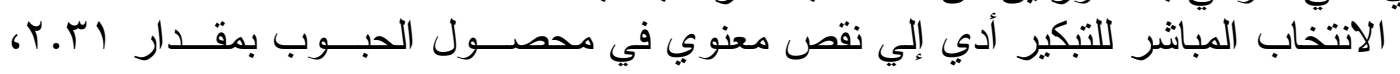

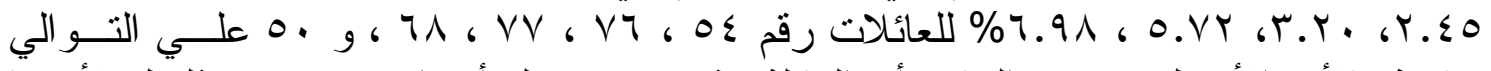

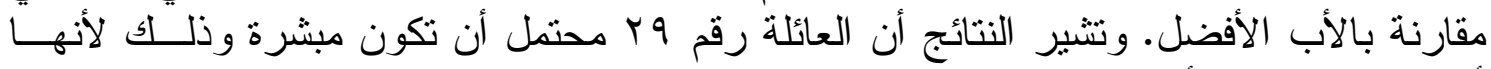

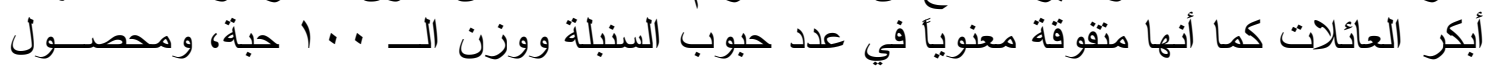
حبوب النبات الفردي. 